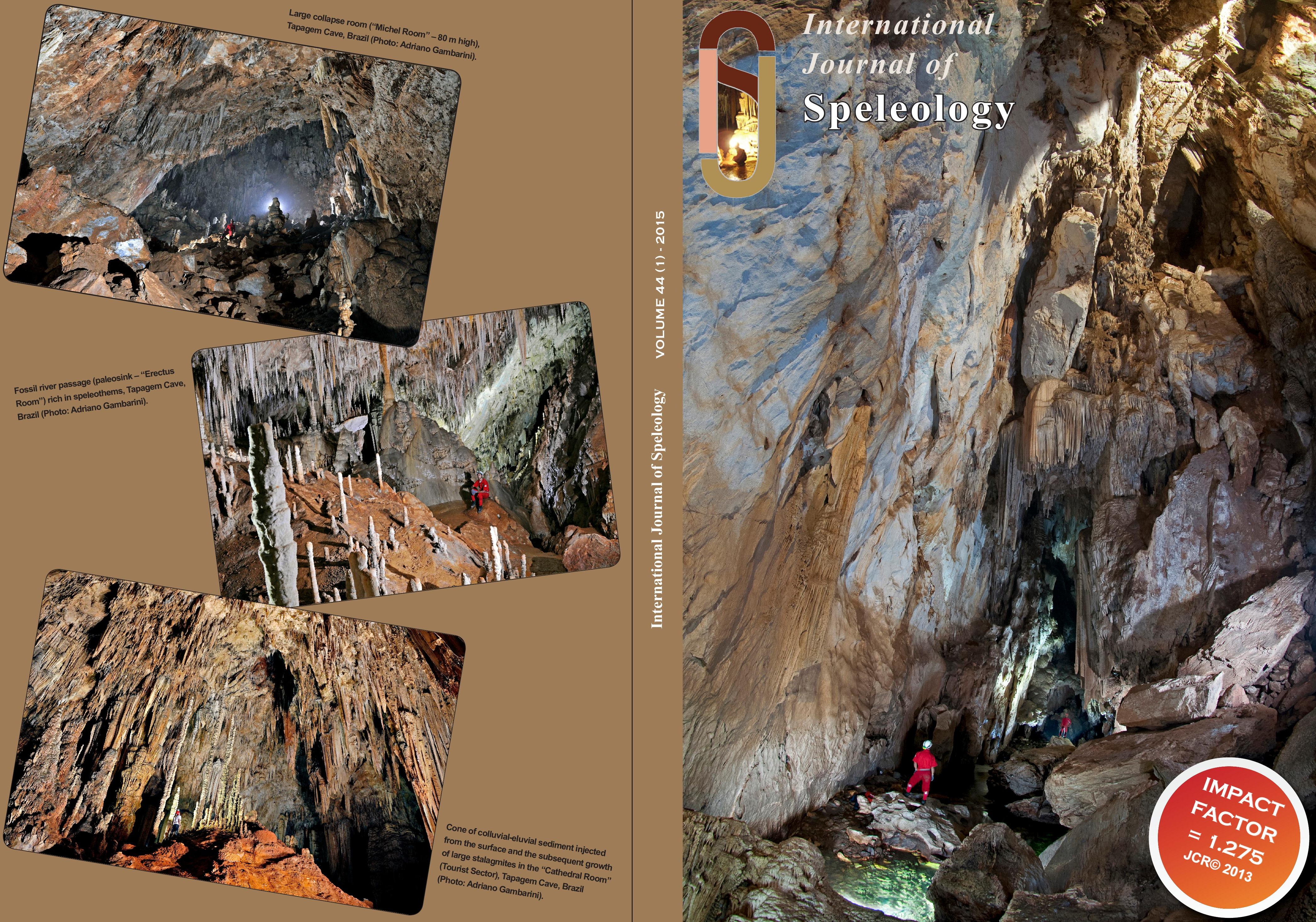




\section{Note to Contributors}

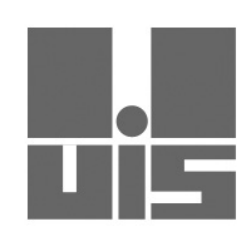

International Journal of Speleology

Official Journal of the Union Internationale de Spéléologie (UIS) Volume 44 (1), January 2015

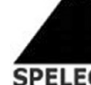

Cooperation agreement with Speleogenesis and Evolution of Karst Aquifers

\section{EDITOR-IN-CHIEF}

Bogdan P. ONAC

School of Geosciences, University of South Florida, 4202 E. Fowler Ave., NES 107, Tampa, FL 33620, USA

Tel.: +1 8139741067 - Fax: +1 8139742654 - E-mail: bonac@usf.edu

\section{ASSOCIATE EDITORS}

Biospeleology

Karst Research Institute, Titov trg. 2, SI-6230, Postojna, Slovenia E-mail: pipan@zrc-sazu.si

\section{Physical Speleology}

Jo DE WAELE

Istituto Italiano di Speleologia, University of Bologna, Via Zamboni 67, I-40126 BOLOGNA (Italy) Tel.: +390512094543 - Fax: +390512094522 - E-mail: jo.dewaele@unibo.it

\section{EDITORIAL STAFF}

José Maria Calaforra (Spai

Russell Drysdale (Australia)

Franci Gabrovšek (Slovenia)

Zaihua Liu (China)

David J. Lowe (UK)

Arthur N. Palmer (USA)

Kyung Sik Woo (Korea)

\section{U.I.S. REPRESENTATIVE}

Paolo Forti (Italy)

\section{INTERNATIONAL EDITORIAL BOARD}

Bartolomé Andreo (Spain)

Ezio Burri (Italy)

Arrigo A. Cigna (Italy)

Stephen A. Craven (S. Africa)

Dominique Genty (Fra
Carol Ann Hill (USA)

Cesareo Saiz-Jimenez (Spain)

Derek C. Ford (Canada)

Philippe Häuselmann (Switzerland)

Alexander Klimchouk (Ukraine)

Andrej Kranjc (Slovenia)

Stein-Erik Lauritzen (Norway)

Fadi Nader (Lebanon)

Diana Northup (USA)

Sergio Sanchez-Moral (Spain)

Ugo Sauro (Italy)

Trevor R. Shaw (UK)
Peter L. Smart (UK)

Ming Tan (China)

William White (USA)

Paul Williams (New Zealand)

\section{Aims and Scope}

The International Journal of Speleology publishes research papers, review
articles and technical col articles and
sciences.

\section{Copyright
() Union Inters}

national de Spéléologie. All rights reserved.Statements and opinions expressed in the articles and communications are those of the authors
and not the statements and opinions of the Union Internationale de Speléologie.

\section{Abstracting and Indexing}

The International Journal of Speleology is included in the Directory of open access services: ISI Thomson Services (Science Citation Index-Expanded including the Web of Science, ISI Alerting Service, Current Contents/Physical, Chemical \& Earth Sciences), Bibliography \& Index of Geology (GeoRef), Cambridge Scientific

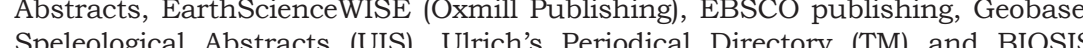
Speleological Abstracts (UIS), Ulrich's Periodical Directory (TM) and BIOSIS
Zoological Record.

\section{Production Team}

Paul Alexandru Onac
Brenna Mathiasen

Brenna Mathiasen
Carol Ann Borchert

Impact Factor 1.275 (JCR Science Edition $\odot$ 2013)

Cover Photo: A 70-m high canyon in the River Passage and the upper leve passages ("Rede Gava"), Tapagem Cave, Brazil (Photo: Adriano Gambarini).
Andrzej Tyc (Poland)

1. Papers should be submitted online at http://scholarcommons.usf.edu/ijs/through the "Submit Article" link. Texts should be typed 1.5 line spaced and have continuous numbered lines, preferably using Times New Roman 12 pt font, and should contain all figures, tables or plates. Tables, plates, and figures, with captions, should be placed after the reference list using the format of IJS (see most recent issues). For the size.

2. Figures, plates, and tables should be sent at full resolution only after the review process is completed, and then in separate files (e.g. Fig1.jpg or Fig1.tiff, Tab1.doc or Tab1.xls). To do so, highlight "Supplemental Files" while submitting your revised manuscript, then upload your supplemental files and their short be taken to imply that it is unpublished and is not being considered for publication elsewhere.

3. Papers should preferably be written in English. Authors using a language other than their own are requested be used. Dates should be in the form " 5 February $1975^{\prime}$ " numbers as $21.6^{\circ} \mathrm{C}$ (and not $12,6^{\circ} \mathrm{C}$ ). Complex formulas and equations should be inserted in the text but after the review process is completed; these must also be sent separately as good-quality .jpg files. 4. Papers should be headed by a title, the full name(s), business address(es) and e-mail address(es) of the author, the name of the person to whom correspondence and proofs should be sent must be followed by * Abstract should be short and summarise the contents of the paper. Authors should provide five keywords after the abstract. Keywords are separated by a ;. Articles can be structured in 3 orders of headings: e.g. GEOLOGY, Lithology, mineralogical characteristics. See recent issues for examples.

5. Each paper will be subject to editorial review by three referees. The Editorial Staff reserves the rights to refuse any manuscript submitted, whether by invitation or otherwise, and to make suggestions and modifications before publication. Submitted papers should be in a final form ready for publication. Make sure figures are of good quality. Correction to proofs should be restricted to printing and editorial errors only. Other than these, the cost of very substantial alterations may be charged to the author(s). 6. Bibliographical references should be listed in alphabetical and chronological order at the end of the paper.
Journal names should not be abbreviated. See most recent issues for examples. References should be in the following forms:

Article: Klimchouk A.B., Andrejchouk V.N. \& Turchinov I.I., 1995 - Structural pre-requisites of speleogenesis in gypsum in the Western Ukraine. Kiev: Ukrainian Speleol. Assoc.: 104 p. (Russian and English). Osborne R.A.L., 2002 - Cave breakdown by vadose weathering. International Journal of Speleology, 31 (1-4): $37-53$

Book: Palmer A.N., 2007 - Cave Geology. Cave Books, Dayton, 454 p.

Chapter: Martinelli G. 1993 - Radon geochemistry and geophysics in deep fluids in Italy. In: Furlan G. \& Tommasino L. (Eds.) - Radon Monitoring in Radioprotection, Environmental and Earth Sciences. \& Tommasino L. (Eds.) - Rad

Palmer A. N. \& Palmer M. V., 2000a - Speleogenesis of the Black Hills maze caves, South Dakota, USA. In: Klimchouk A., Ford D. C., Palmer A. N. \& Dreybrodt W. (Eds.), Speleogenesis. Evolution of karst aquifers. Huntsville: National Speleological Society: $274-281$.

7. References should be cited in the text in parentheses, e.g. "(Jones, 1961)" except when the author's name is part of the sentence, e.g. "Jones (1961) has shown that...". When reference is made more than once to the same author and year, a, b, c, etc. should be added to the date in the text and in the reference list. For two et al.,1995). Multiple citations are listed in chronological order and separated by ; e.g. (White et al., 1988; Palmer, 2001).

8. After the review process is completed, each table should be supplied in separate files. Tables should be numbered using Arabic numerals, e.g. "Table 1", etc. Should a table not be an original, a full reference to as simple as possible.

9. After the review process is completed, color figures should be supplied in separate files. Figures should be numbered using Arabic numerals, e.g. "Fig. 1", etc. and must be cited in the text close to where they Figures and photographs should be supplied with appropriate captions, and kept as simple as possible. Please use same font size when generating your figures or plates.

10. Letters to the Editorial Staff should relate to single topics, provide comment on editorial policy or discuss the content of the International Journal of Speleology, or be responses to comments published in earlier issues of the journal.

11. Articles accepted by the Editorial Staff will become the property of the Publisher and may not be reprinted or translated without the written permission of the Publisher

12. The Editor and the Publisher of the International Journal of Speleology are not responsible for the scientific content or other statements provided by the authors of accepted papers. 